\title{
Anammox, denitrification and fixed-nitrogen removal in sediments from the Lower St. Lawrence Estuary
}

\author{
S. A. Crowe ${ }^{1}$, D. E. Canfield ${ }^{1}$, A. Mucci $^{2}$, B. Sundby ${ }^{2}$, and R. Maranger ${ }^{3}$ \\ ${ }^{1}$ Nordic Center for Earth Evolution (NordCEE), Institute of Biology, University of Southern Denmark, Odense, Denmark \\ ${ }^{2}$ GEOTOP and Department of Earth and Planetary Sciences, McGill University, Montréal, Canada \\ ${ }^{3}$ Département de sciences biologiques, Université de Montréal, Montréal, Canada
}

Correspondence to: S. A. Crowe (sacrowe1@gmail.com)

Received: 11 July 2011 - Published in Biogeosciences Discuss.: 21 September 2011

Revised: 1 August 2012 - Accepted: 20 August 2012 - Published: 7 November 2012

\begin{abstract}
Incubations of intact sediment cores and sediment slurries reveal that anammox is an important sink for fixed nitrogen in sediments from the Lower St. Lawrence Estuary (LSLE), where it occurs at a rate of $5.5 \pm$ $1.7 \mu \mathrm{mol} \mathrm{N} \mathrm{m} \mathrm{m}^{-2} \mathrm{~h}^{-1}$. Canonical denitrification occurs at a rate of $11.3 \pm 1.1 \mu \mathrm{mol} \mathrm{N} \mathrm{m}{ }^{-2} \mathrm{~h}^{-1}$, and anammox is thus responsible for up to $33 \%$ of the total $\mathrm{N}_{2}$ production. Both anammox and denitrification are mostly ( $>95 \%)$ fueled by nitrate and nitrite produced in situ through benthic nitrification. Nitrification accounts for $>15 \%$ of the benthic oxygen demand and may, therefore, contribute significantly to the development and maintenance of hypoxic conditions in the LSLE. The rate of dissimilatory nitrate reduction to ammonium is three orders of magnitude lower than denitrification and anammox, and it is insignificant to $\mathrm{N}$-cycling. $\mathrm{NH}_{4}^{+}$ oxidation by sedimentary $\mathrm{Fe}(\mathrm{III})$ and $\mathrm{Mn}(\mathrm{III} / \mathrm{IV})$ in slurry incubations with $\mathrm{N}$ isotope labels did not occur at measurable rates; moreover, we found no evidence for $\mathrm{NH}_{4}^{+}$oxidation by added Mn(III)-pyrophosphate.
\end{abstract}

\section{Introduction}

The Laurentian Great Lakes-St. Lawrence drainage basin covers about $1.32 \times 10^{6} \mathrm{~km}^{2}$ and is home to approximately 35 million North Americans. The St. Lawrence RiverEstuary provides the second largest freshwater discharge $\left(11900 \mathrm{~m}^{3} \mathrm{~s}^{-1}\right)$ to the ocean in North America and is subject to extensive anthropogenic $\mathrm{N}$ loading from urban, industrial and agricultural sources (Gilbert et al., 2007).
In estuarine systems, $\mathrm{N}$ often limits primary production (Capone et al., 2008), and coastal eutrophication, resulting from nitrogen loading to rivers and estuaries, is a growing global concern (Cloern, 2001; Capone et al., 2008; Breitburg et al., 2009). In a stratified body of water, eutrophication is most often reflected by increased microbial oxygen demand and decreased oxygen availability to both benthic and pelagic organisms (Cloern, 2001; Breitburg et al., 2009). Eutrophication has been implicated in the progressive development of hypoxic bottom waters in the Lower St. Lawrence Estuary (LSLE) over the last century (Thibodeau et al., 2006; Gilbert et al., 2005; Gilbert et al., 2007).

The ability of a system to buffer anthropogenic $\mathrm{N}$ loading and resist the ensuing eutrophication rests largely on its capacity to remove fixed forms of $\mathrm{N}$ through the production and loss of $\mathrm{N}_{2}$ gas (Capone et al., 2008). Two biogeochemical reactions, denitrification and anammox (see Fig. 1 for a schematic representation of the sedimentary $\mathrm{N}$-cycle) account for nearly all $\mathrm{N}_{2}$ production and fixed-N loss from marine and freshwater ecosystems (Canfield et al., 2005; Capone et al., 2008). The microorganisms responsible for these reactions are highly sensitive to oxygen, and marine $\mathrm{N}_{2}$ production is therefore largely confined to anoxic environments, including coastal sediments and oxygen minimum zones (Capone et al., 2008; Canfield et al., 2005). Bottom waters over much of the LSLE are hypoxic (Gilbert et al., 2005) with $\mathrm{O}_{2}$ concentrations as low as $50 \mu \mathrm{mol} 1^{-1}$, but water column denitrification is only known to occur at $\mathrm{O}_{2}$ concentrations $<4 \mu \mathrm{mol} 1^{-1}$ (Codispoti et al., 2001), and the enzymes responsible for complete denitrification exhibit varying degrees of sensitivity to $\mathrm{O}_{2}$ (Zumft, 1997). 


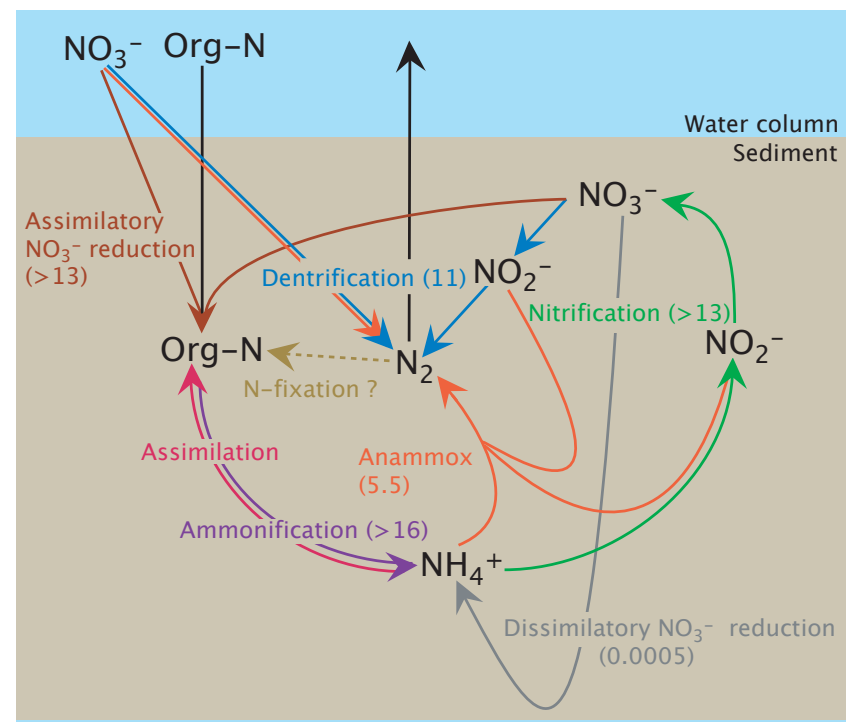

Fig. 1. Schematic illustration of the sedimentary N-cycle in the Lower St. Lawrence Estuary (LSLE). Numbers in parentheses are the rates in $\mu \mathrm{mol} \mathrm{m} \mathrm{m}^{-2} \mathrm{~h}^{-1}$.

Anammox bacteria are believed to be more $\mathrm{O}_{2}$ tolerant, but they still appear to require $\mathrm{O}_{2}$ concentrations below $10 \mu \mathrm{moll}^{-1}$ (Kuypers et al., 2005; Jensen et al., 2008). Thus, most fixed-N loss in the LSLE likely occurs in the underlying sediment.

Rates of sediment $\mathrm{N}_{2}$ production in the LSLE have been: (1) measured directly using the original isotope-pairing technique (IPT) (Wang et al., 2003); (2) estimated from $\mathrm{NO}_{3}^{-}$and $\mathrm{N}_{2}$ fluxes (Thibodeau et al., 2010; Katsev et al., 2007) and water column nitrogen deficits (Thibodeau et al., 2010); and (3) derived from diagenetic modeling (Katsev et al., 2007). Although there is variability in the reported rates, the diverse methods used yield a generally coherent picture of fixed-N removal in the LSLE: relatively high rates of $\mathrm{N}_{2}$ production in the sediment with in situ benthic nitrification contributing significantly to the $\mathrm{NO}_{3}^{-}$supply. The most recent study suggests that fixed-N removal through sedimentary $\mathrm{N}_{2}$ production is nearly sufficient to balance nitrate inputs from the St. Lawrence River and that little nitrate exits to the Gulf of St. Lawrence (Thibodeau et al., 2010). Despite our relatively comprehensive understanding of the LSLE N-budget, the different fixed-N removal pathways have yet to be determined (Thibodeau et al., 2010) and the importance of anammox is unknown. Accurate partitioning of N-removal pathways is now possible with a recent refinement of the original isotope-pairing technique (IPT) to determine anammox rates in sediments (Risgaard-Petersen et al., 2003; Trimmer and Nicholls, 2009; Trimmer et al., 2006). Our ability to predict productivity, eutrophication, and hypoxia and their relationships in the LSLE depends on our knowledge of the specific biogeochemical processes involved.
The ubiquity of anammox in continental shelf sediments and the deep sea is becoming clear, but the factors regulating its relative importance to total $\mathrm{N}_{2}$ production remain poorly known (Trimmer and Nicholls, 2009; Thamdrup and Dalsgaard, 2008; Francis et al., 2007). In shelf and deep-sea sediments, the importance of anammox to total $\mathrm{N}_{2}$ production is positively correlated with water depth (Thamdrup and Dalsgaard, 2002; Trimmer and Nicholls, 2009). This correlation was explained by the progressive decrease with depth in the delivery of reactive organic matter to the sediments (Thamdrup and Dalsgaard, 2002; Dalsgaard et al., 2005); heterotrophic denitrification would be limited by the availability of these organic substrates, and the chemoautotrophic anammox process should be comparably insensitive. Anammox activity is also modulated by temperature (Dalsgaard and Thamdrup, 2002; Rysgaard et al., 2004) and the supply of nitrite either produced in situ via nitrification or diffusing from overlying water (Meyer et al., 2005; Risgaard-Petersen et al., 2005; Trimmer et al., 2005).

Anammox has also been detected in a number of estuaries (Trimmer et al., 2003, 2005; Meyer et al., 2005; Rich et al., 2008). The most comprehensive study to date (Nicholls and Trimmer, 2009) reports that anammox is important to $\mathrm{N}_{2}$ production in numerous estuaries of the UK with a maximum contribution of $11 \%$ in the Medway. In the UK estuaries, the contribution of sedimentary anammox to $\mathrm{N}_{2}$ production is positively correlated with nitrate concentrations in the overlying waters and with sediment organic content (Nicholls and Trimmer, 2009). Given the ubiquity of the anammox reaction in marine sediments and its importance to $\mathrm{N}_{2}$ production in UK estuaries, it is also likely important to $\mathrm{N}_{2}$ production in the LSLE. However, most of the historical information on anammox activity is based on slurry incubations, which translate poorly to in situ rates, and the heterogeneity of estuarine ecosystems precludes reliable extrapolation of data from UK estuaries to estuaries in general (Capone et al., 2008).

An alternative pathway for $\mathrm{N}_{2}$ production, through the direct oxidation of $\mathrm{NH}_{4}^{+}$by (hydr)oxides of $\mathrm{Fe}$ and $\mathrm{Mn}$ in sediment of the LSLE, has also been proposed (Luther et al., 1997; Anschutz et al., 2000). Although thermodynamically favorable (Luther et al., 1997), conclusive evidence for the operation of this pathway in the environment remains elusive. Early tests of this pathway found no evidence for Mn-dependent $\mathrm{NH}_{4}^{+}$oxidation in Mn-rich Skagerrak sediments but instead yielded early evidence for anammox in natural environments (Thamdrup and Dalsgaard, 2000). More recently, Fe-dependent $\mathrm{NH}_{4}^{+}$oxidation has been reported in wetland soils (Clement et al., 2005; Shrestha et al., 2009) and wastewaters (Park et al., 2009), but the veracity of these reports remains untested and their significance is unknown. Porewater profiles in deep Indian Ocean sediments have recently provided indirect evidence for the oxidation of $\mathrm{NH}_{4}^{+}$ by sulfate, despite the marginal thermodynamic yield of this reaction (Schrum et al., 2009). The discovery of soluble 
$\mathrm{Mn}(\mathrm{III})$ species in the anoxic waters of the Black Sea and Chesapeake Bay (Trouwborst et al., 2006) and in the porewaters of the LSLE (Madison et al., 2011) raises the possibility that an additional oxidant, with the thermodynamic potential to oxidize $\mathrm{NH}_{4}^{+}$to $\mathrm{N}_{2}, \mathrm{NO}_{2}^{-}$or $\mathrm{NO}_{3}^{-}$in the absence of $\mathrm{O}_{2}$, may play a role in the $\mathrm{N}$-cycle. Overall, the available evidence for alternative pathways of fixed-N conversion to $\mathrm{N}_{2}$ is inconclusive and warrants further investigation. In this work, we report quantitative rate measurements of anammox and denitrification, we partition the fixed- $\mathrm{N}$ removal reactions, and test for alternative pathways to $\mathrm{N}_{2}$ in sediments from the Lower St. Lawrence Estuary.

\section{Methods}

\subsection{Site description}

The $300 \mathrm{~km}$ long, $50 \mathrm{~km}$ wide, and $0.3 \mathrm{~km}$ deep Lower St. Lawrence Estuary (LSLE) occupies the landward portion of the Laurentian Trough, a glacial bathymetric feature that extends $1200 \mathrm{~km}$ landward from the edge of the continental shelf (Fig. 2). Due to its great depth, the water column in the LSLE is permanently stratified with net seaward flow in the surface layer and net landward flow in the bottom layer (Saucier et al., 2003). Sediments in the channel are composed of fine-grained particulates (pelites) with, on average, $60 \%$ clay, $35 \%$ silt and $5 \%$ sand (Nota and Loring, 1964). The sediments are dark yellowish-brown in the first 1$3 \mathrm{~cm}$ below the sediment-water interface, reflecting the presence of detrital and authigenic ferric iron [Fe(III)] and manganic [Mn(IV)] minerals (Loring and Nota, 1968; Lyle, 1983; Konig et al., 1997). Below this oxidized layer, the sediments are dark greenish-grey (Loring and Nota, 1968).

\subsection{Sampling}

All samples were collected during a cruise in the Lower St. Lawrence Estuary (LSLE) on the R/V Coriolis II in July of 2009. Surface and bottom water samples were collected using a $12 \times 12-1$ Niskin bottle/CTD rosette (SeaBird SBE 911). The core used for the incubations was recovered at Station 23: $48^{\circ} 42.032^{\prime} \mathrm{N}, 68^{\circ} 39.171^{\prime} \mathrm{W} ; 345 \mathrm{~m}$ depth. Overlying water $\mathrm{O}_{2}, \mathrm{NO}_{3}^{-}$and soluble reactive phosphate (SRP) concentrations were $63 \mu \mathrm{moll}^{-1}, 34 \mu \mathrm{moll}^{-1}$ and $2.7 \mu \mathrm{mol} \mathrm{l}^{-1}$, respectively. Sediments were recovered with minimal disturbance using an Ocean Instruments Mark II box corer $(20 \times 30 \times 50 \mathrm{~cm})$. The sediments were sectioned at various intervals in a glove box continuously flushed with $\mathrm{N}_{2}$ to avoid oxidation artifacts (Edenborn et al., 1986), and porewaters were extracted with a $\mathrm{N}_{2}$ overpressure using modified "Reeburgh-type" squeezers (Reeburgh, 1967; Mucci et al., 2000). Sediments for intact core incubations were subsampled from a second box core with 6 acrylic tubes $(5.2 \mathrm{~cm}$ in diameter and $60 \mathrm{~cm}$ in length). Fresh bottom water was

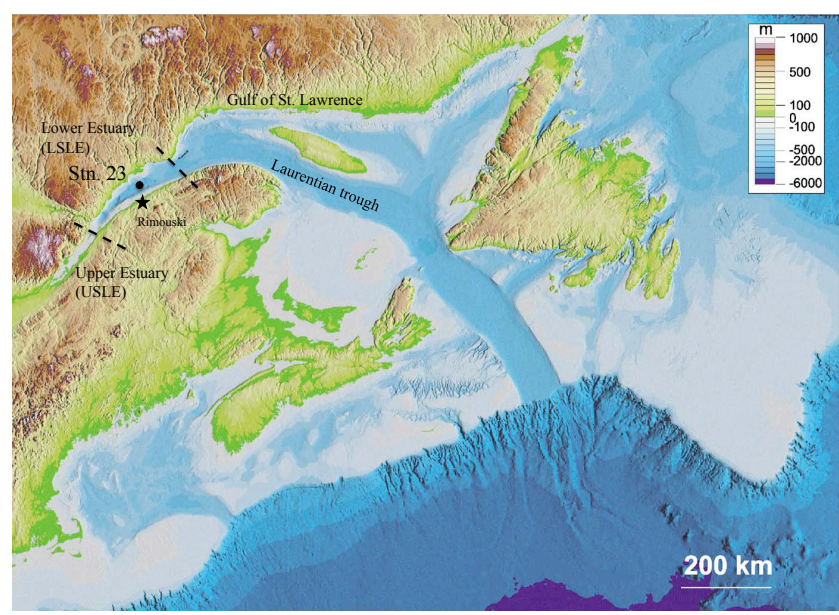

Fig. 2. Map of the St. Lawrence Estuary showing the location of Station $23\left(48^{\circ} 42.032^{\prime} \mathrm{N}, 68^{\circ} 39.171^{\prime} \mathrm{W} ; 345 \mathrm{~m}\right.$ depth), and delineating the extent of the Lower Estuary (LSLE). Modified from Shaw et al. (2002).

added to these sub-cores to replace the water lost during box core recovery and subsequent sub-coring.

\subsection{Slurry incubations}

Sediment slurries were prepared by mixing sediment from the top $2 \mathrm{~cm}$ of the box core with an equivalent volume of bottom water that was previously purged with ultra-highpurity $\mathrm{He}$ gas to remove $\mathrm{O}_{2}$ and $\mathrm{N}_{2}$. The sediment slurry was subsequently purged with $\mathrm{He}$ for an additional $12 \mathrm{~h}$ to remove residual $\mathrm{N}_{2}$ gas and allow $\mathrm{NO}_{3}^{-}$present in the bottom water and sediment porewaters to be consumed. Following this 12 -h period, the sediment slurry was transferred, with no headspace, into ninety $12-\mathrm{ml}$ gas tight vials (Exetainers, LabCo). Isotopic labels, substrates, and specific inhibitors were added as shown in Table 1 . The predicted ${ }^{15} \mathrm{~N}-$ labeled $\mathrm{N}_{2}$ products of the individual experiments for a given process are presented in Table 2 . The sediment slurries were incubated at $4{ }^{\circ} \mathrm{C}$, close to the in situ bottom water temperature of $4.7^{\circ} \mathrm{C}$, mixed periodically by inversion, and sacrificed over an interval of $36 \mathrm{~h}$. Upon sacrificing, $1 \mathrm{ml}$ of slurry was removed from the Exetainer using a needle and syringe and replaced with $\mathrm{He}$ gas and $200 \mu \mathrm{l}$ of a $37 \%$ formaldehyde solution to stop microbial activity. The withdrawn sediment slurry $(1 \mathrm{ml})$ was filtered directly through a $0.2 \mu \mathrm{m}$ pore size syringe filter and the filtrate was frozen for later analysis. The formaldehyde-fixed sediment slurry was stored upside down in the Exetainers until isotopic analysis.

\subsection{Intact core incubations}

Our intact core incubations followed the refined IPT protocol described by Trimmer and Nicholls (2009), in which the isotopic composition of $\mathrm{NO}_{3}^{-}$within the zone of denitrification 
Table 1. Slurry incubation conditions (label additions) and labeled $\mathrm{N}_{2}$ production rates: series A received $10 \mu \mathrm{l}$ of a $100 \mathrm{mmol} \mathrm{l}^{-1}$ solution of ${ }^{15} \mathrm{~N}_{-} \mathrm{NH}_{4}^{+}$; series B received $10 \mu \mathrm{l}$ of a $100 \mathrm{mmoll}^{-1}$ solution of ${ }^{15} \mathrm{~N}-\mathrm{NO}_{3}^{-}$; series $\mathrm{C}$ received $10 \mu \mathrm{l}$ of a $100 \mathrm{mmol} \mathrm{l}^{-1}$ solution of ${ }^{15} \mathrm{~N}$ -

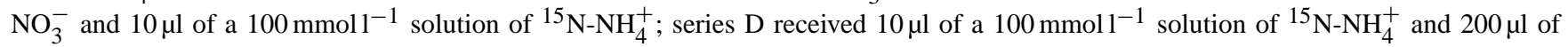
a $10 \mathrm{mmoll}^{-1}$ solution of allylthiourea (ATU), a specific inhibitor of nitrification; series E received $10 \mu \mathrm{l}$ of a $100 \mathrm{mmol} \mathrm{l}^{-1}$ solution of ${ }^{15} \mathrm{~N}_{-} \mathrm{NH}_{4}^{+}$and $200 \mu \mathrm{l}$ of a freshly prepared $40 \mathrm{mmoll}^{-1}$ solution of $\mathrm{Mn}(\mathrm{III})$-pyrophosphate; and series $\mathrm{F}$ received $10 \mu \mathrm{l}$ of a $100 \mathrm{mmol} \mathrm{l}^{-1}$ solution of ${ }^{15} \mathrm{~N}_{-} \mathrm{NH}_{4}^{+}, 10 \mu \mathrm{l}$ of a $100 \mathrm{mmol}^{-1}$ solution of ${ }^{15} \mathrm{~N}^{-\mathrm{NO}_{3}^{-}}$and $200 \mu \mathrm{l}$ of a $10 \mathrm{mmol}^{-1}$ solution of ATU.

\begin{tabular}{|c|c|c|c|c|c|}
\hline Treatment & $\begin{array}{r}{ }^{15} \mathrm{~N}-\mathrm{NO}_{3}^{-} \\
\quad(\mu \mathrm{mol}\end{array}$ & $\begin{array}{l}{ }^{15} \mathrm{~N}-\mathrm{NH}_{4}^{+} \\
\left.\mathrm{m}^{-3}\right)\end{array}$ & other & $\begin{array}{l}{ }^{29} \mathrm{~N}_{2} \\
\left(\times 10^{-4} \mu\right.\end{array}$ & $\begin{array}{l}{ }^{30} \mathrm{~N}_{2} \\
\left.\mathrm{lol} \mathrm{cm}^{-3} \mathrm{~h}^{-1}\right)\end{array}$ \\
\hline A & & 0.08 & & & \\
\hline B & 0.08 & & & $6.6 \pm 0.7$ & $3.3 \pm 0.6$ \\
\hline $\mathrm{C}$ & 0.08 & 0.08 & & $6 \pm 1$ & $3.8 \pm 0.2$ \\
\hline $\mathrm{D}$ & & 0.08 & $0.165 \mu \mathrm{mol} \mathrm{cm}{ }^{-3}$ ATU & & \\
\hline $\mathrm{E}$ & & 0.08 & $0.635 \mu \mathrm{mol} \mathrm{cm}{ }^{-3} \mathrm{Mn}-\mathrm{PP}^{*}$ & & \\
\hline $\mathrm{F}$ & 0.08 & 0.08 & $0.165 \mu \mathrm{mol} \mathrm{cm}{ }^{-3}$ ATU & $9 \pm 1$ & $5 \pm 0.3$ \\
\hline
\end{tabular}

*PP stands for pyrophosphate

Table 2. Predicted outcomes for slurry incubations (assuming no DNRA). The bold X's mark the observed labeling. The emphasized row highlights the combination of processes (denitrification and anammox) operative in the LSLE sediments (data in Fig. 4). $W=$ Denitrification, $X=$ Anammox, $Y=\mathrm{Mn}$ and $\mathrm{Fe}$ dependent $\mathrm{NH}_{4}^{+}$oxidation to $\mathrm{N}_{2}, Z=\mathrm{Mn}$ and $\mathrm{Fe}$ dependent $\mathrm{NH}_{4}^{+}$oxidation to $\mathrm{NO}_{\mathrm{x}}$.

\begin{tabular}{|c|c|c|c|c|c|c|c|c|c|c|c|c|}
\hline & \multicolumn{2}{|c|}{ A } & \multicolumn{2}{|c|}{ B } & \multicolumn{2}{|c|}{$\mathrm{C}$} & \multicolumn{2}{|c|}{ D } & \multicolumn{2}{|c|}{$\mathrm{E}$} & \multicolumn{2}{|c|}{$\mathrm{F}$} \\
\hline & ${ }^{29} \mathrm{~N}_{2}$ & ${ }^{30} \mathrm{~N}_{2}$ & ${ }^{29} \mathrm{~N}_{2}$ & ${ }^{30} \mathrm{~N}_{2}$ & ${ }^{29} \mathrm{~N}_{2}$ & ${ }^{30} \mathrm{~N}_{2}$ & ${ }^{29} \mathrm{~N}_{2}$ & ${ }^{30} \mathrm{~N}_{2}$ & ${ }^{29} \mathrm{~N}_{2}$ & ${ }^{30} \mathrm{~N}_{2}$ & ${ }^{29} \mathrm{~N}_{2}$ & ${ }^{30} \mathrm{~N}_{2}$ \\
\hline W & & & & $\mathbf{X}$ & & $\mathbf{X}$ & & & & & & $\mathbf{X}$ \\
\hline$X$ & & & $\mathbf{X}$ & & $\mathbf{X}$ & $\mathbf{X}$ & & & & & $\mathbf{X}$ & $\mathbf{X}$ \\
\hline $\mathrm{Y}$ & $\mathrm{X}$ & $\mathrm{X}$ & & & $\mathrm{X}$ & $X$ & $\mathrm{X}$ & $\mathrm{X}$ & $X$ & $\mathrm{X}$ & $\mathrm{X}$ & $\mathrm{X}$ \\
\hline $\mathrm{Z}$ & & & & & & & & & & & & \\
\hline $\mathrm{W}, \mathrm{X}$ & & & $\mathbf{X}$ & $\mathbf{X}$ & $\mathbf{X}$ & $\mathbf{X}$ & & & & & $\mathbf{X}$ & $\mathbf{X}$ \\
\hline $\mathrm{W}, \mathrm{Y}$ & $\mathrm{X}$ & $\mathrm{X}$ & & $\mathrm{X}$ & $\mathrm{X}$ & $\mathrm{X}$ & $\mathrm{X}$ & $\mathrm{X}$ & $X$ & $\mathrm{X}$ & $X$ & $\mathrm{X}$ \\
\hline $\mathrm{W}, \mathrm{X}, \mathrm{Y}$ & $X$ & $\mathrm{X}$ & $X$ & $X$ & $X$ & $\mathrm{X}$ & $\mathrm{X}$ & $X$ & $\mathrm{X}$ & $\mathrm{X}$ & $X$ & $\mathrm{X}$ \\
\hline $\mathrm{W}, \mathrm{Z}$ & $X$ & $\mathrm{X}$ & $X$ & $\mathrm{X}$ & $X$ & $\mathrm{X}$ & $X$ & $X$ & $X$ & $\mathrm{X}$ & $\mathrm{X}$ & $\mathrm{X}$ \\
\hline $\mathrm{X}, \mathrm{Z}$ & $X$ & $\mathrm{X}$ & $\mathrm{X}$ & & $X$ & $X$ & $X$ & $X$ & $X$ & $\mathrm{X}$ & $X$ & $\mathrm{X}$ \\
\hline $\mathrm{Y}, \mathrm{Z}$ & $X$ & $X$ & & & $X$ & $X$ & $X$ & $X$ & $X$ & $X$ & $X$ & $X$ \\
\hline $\mathrm{W}, \mathrm{X}, \mathrm{Y}, \mathrm{Z}$ & $\mathrm{X}$ & $X$ & $X$ & $X$ & $\mathrm{X}$ & $\mathrm{X}$ & $X$ & $\mathrm{X}$ & $X$ & $\mathrm{X}$ & $X$ & $\mathrm{X}$ \\
\hline
\end{tabular}

is determined from the isotopic composition of $\mathrm{N}_{2} \mathrm{O}$, which is produced as an intermediate during denitrification, but not during anammox. Unlike previous versions of the IPT protocol, which relied either on slurry incubations or a concentration series of intact core incubations to estimate the isotopic composition of $\mathrm{NO}_{3}^{-}$in the $\mathrm{NO}_{3}^{-}$reduction zone, the refinement permits both denitrification and anammox rates to be calculated using a single set of intact sediment cores without slurries. Following sub-coring and replacement of the overlying water, magnetic stirring devices were inserted into the tubes and suspended $3 \mathrm{~cm}$ above the sediment-water interface. Each sub-core was allowed to stand and re-equilibrate at $4{ }^{\circ} \mathrm{C}$ for approximately $12 \mathrm{~h}$ to near in situ temperatures while the overlying water was stirred. After the equilibration period, $1.5 \mathrm{ml}$ of a $100 \mathrm{mmoll}^{-1}$ solution of ${ }^{15} \mathrm{~N}^{-N^{-}}{ }_{3}^{-}$was added to the overlying water. Following an additional $6 \mathrm{~h}$, the overlying water was sampled for the determination of $\mathrm{N}$ species, and the sub-cores were sealed with no headspace using thick butyl rubber stoppers. The 6 sub-cores were periodically sacrificed over the next $34 \mathrm{~h}$, upon which stirring was halted and the stoppers carefully removed. The overlying water was sampled for $\mathrm{NO}_{\mathrm{x}}$ and $\mathrm{NH}_{4}^{+}$analyses. Subsequently, the top $2 \mathrm{~cm}$ of the sediment were gently mixed into the overlying water using a plastic rod. A syringe, fitted with a steel canula, was used to withdraw the slurry from $>10 \mathrm{~cm}$ below the water surface to avoid atmospheric $\mathrm{N}_{2}$ contamination. This slurry was transferred to 12-ml Exetainers, which were flushed with $\sim 36 \mathrm{ml}(3 \times$ the Exetainer volume) of slurry. To stop microbial activity, $200 \mu \mathrm{l}$ of $37 \%$ formaldehyde was added and the Exetainers closed without headspace. Samples were collected using this same technique for membrane inlet mass spectroscopy (MIMS) (Kana 
et al., 1994). Triplicate samples were collected in 7-ml glass tubes, fixed with $25 \mu \mathrm{l} 0.1 \mathrm{moll}^{-1} \mathrm{HgCl}_{2}$ and sealed with a ground-glass stopper. These tubes were submerged in water and kept cold until analysis. An additional portion of the slurry was transferred to a plastic centrifuge tube and frozen for later analysis of ${ }^{15} \mathrm{~N}_{-} \mathrm{NH}_{4}^{+}$. Rate calculations based on these measurements are described in Appendix A.

\subsection{Analyses}

Porewater $\mathrm{O}_{2}$ was measured with a Unisense PA2000 picoammeter and a Unisense "Clark" type microelectrode fitted with a stainless steel needle tip to prevent breakage. This electrode was calibrated with two points: Lower St. Lawrence Estuary bottom water saturated in $\mathrm{O}_{2}$ by vigorous stirring in ambient atmosphere, and an anoxic, alkaline ascorbate solution. The detection limit for $\mathrm{O}_{2}$ was $0.2 \mu \mathrm{moll}^{-1}$, calculated from the standard deviation of five background measurements taken in an anoxic, alkaline ascorbate solution. Samples for the measurement of N species concentrations were transported on dry ice back to the NordCEE lab in Denmark and stored frozen until analysis. $\mathrm{NH}_{4}^{+}$concentrations were measured using a gas-exchange, flow-injection method (Hall and Aller, 1992) with a detection limit of $0.1 \mu \mathrm{mol}^{-1}$ and a reproducibility of $5 \% \mathrm{RSD}$. Combined $\mathrm{NO}_{3}^{-}$and $\mathrm{NO}_{2}^{-}$concentrations $\left(\mathrm{NO}_{\mathrm{x}}\right)$ were determined by chemiluminescence (Braman and Hendrix, 1989), $\left(\mathrm{NO}_{\mathrm{x}}\right.$ analyzer model 42c, Thermo Environmental Instruments Inc.) with a detection limit of $<10 \mathrm{nmoll}^{-1}$ and a reproducibility of better than $5 \%$ RSD. The slurry samples designated for isotopic analyses were maintained in their Exetainers at room temperature, and upside down when possible. The isotopic composition of $\mathrm{N}_{2}$ was determined by injecting 25-50 $\mu$ l of headspace gas into an in-house built injection system. Following injection, $\mathrm{CO}_{2}$ was trapped using Ascarite (III), $\mathrm{N}_{2}$ and $\mathrm{N}_{2} \mathrm{O}$ separated using a Poropak R GC column, and the sample stream passed through a reduction reactor to reduce $\mathrm{N}_{2} \mathrm{O}$ to $\mathrm{N}_{2}$ and $\mathrm{O}_{2}$ to $\mathrm{H}_{2} \mathrm{O} . \mathrm{H}_{2} \mathrm{O}$ was trapped on $\mathrm{Mg}$ perchlorate, and the sample stream was introduced using a Conflo III to a Thermo Electron DELTA V plus IR-MS operated in continuous-flow mode. $\mathrm{N}_{2}$ was measured at masses 28 , 29 , and 30. Similarly, the $\mathrm{N}$ isotopic composition of $\mathrm{N}_{2} \mathrm{O}$ was measured by injecting 200-1000 $\mu \mathrm{l}$ of headspace gas, but the reduction reactor was bypassed and isotopic measurements were made on masses 44,45 , and 46. Changes in $\mathrm{N}_{2}$ concentrations and $\mathrm{N}_{2}$ / Ar ratios were measured directly using MIMS (Kana et al., 1994). Measurements of ${ }^{15} \mathrm{~N}-\mathrm{NH}_{4}^{+}$were conducted by converting $\mathrm{NH}_{4}^{+}$to $\mathrm{N}_{2}$ following oxidation by hypobromite, as described by Rysgaard and Risgaard-Petersen, (1997). In the case of the slurry incubations, $\mathrm{NH}_{4}^{+}$was extracted in a $2 \mathrm{moll}^{-1} \mathrm{KCl}$ solution prior to hypobromite oxidation and isotopic analysis. The reactive $\mathrm{Mn}$ and $\mathrm{Fe}$ (hydr)oxide content of the sediment used for our slurry incubations (the upper $2 \mathrm{~cm}$ of the sediment core) was determined using $1 \mathrm{M}$ hydroxylamine- $\mathrm{HCl}$ and citrate- dithionite sequential, selective extractions (Poulton and Canfield, 2005).

\section{Results}

\subsection{Porewater profiles}

Porewater profiles of $\mathrm{O}_{2}, \mathrm{NO}_{\mathrm{x}}$ and $\mathrm{NH}_{4}^{+}$are shown in Fig. 3. After re-establishing thermal equilibrium over several hours open to the ambient atmosphere, $\mathrm{O}_{2}$ concentrations in the water overlying the sediment-water interface were between 40 and $60 \mu \mathrm{moll}^{-1}$. These values are similar to those measured in the bottom waters using both the oxygen sensor (Seabird SBE-42) on the CTD and Winkler titration (Grasshoff et al., 1999; Gilbert et al., 2005). Dissolved oxygen concentrations decreased logarithmically and became undetectable $\left(<0.2 \mu \mathrm{moll}^{-1}\right) 6$ to $9 \mathrm{~mm}$ below the sediment-water interface (SWI). These values are consistent with $\mathrm{O}_{2}$ profiles measured previously (Anschutz et al., 2000; Luther et al., 1998; Katsev et al., 2007). The $\mathrm{NO}_{\mathrm{x}}$ concentration was $23 \mu \mathrm{mol} 1^{-1}$ in the bottom waters and decreased from $3.5 \mu \mathrm{moll}^{-1}$ in the $0-0.5 \mathrm{~cm}$ sediment sampling interval to $0.8 \mu \mathrm{moll}^{-1}$ in the $0.5-1.0 \mathrm{~cm}$ depth interval. Traces of dissolved $\mathrm{NO}_{\mathrm{x}}\left(<1 \mu \mathrm{mol} \mathrm{l}^{-1}\right)$ were detected throughout the core and a small peak in $\mathrm{NO}_{\mathrm{x}}$ was observed between 6 and $8 \mathrm{~cm}$ below the SWI. Ammonium was undetectable $\left(<0.5 \mu \mathrm{mol}^{-1}\right)$ in the bottom waters, increased below the sediment-water interface, and reached a maximum of $115 \mu \mathrm{moll}^{-1}$ approximately $17 \mathrm{~cm}$ below the SWI. The $\mathrm{NO}_{\mathrm{x}}$ and $\mathrm{NH}_{4}^{+}$profiles are consistent with previous measurements (Katsev et al., 2007; Anschutz et al., 2000).

\subsection{Slurry incubations}

The production of ${ }^{15} \mathrm{~N}$-labeled $\mathrm{N}_{2}$ in slurry incubations is shown in Fig. $4 .{ }^{29} \mathrm{~N}_{2}$ is produced from the coupling of a single unlabeled ${ }^{14} \mathrm{~N}$ atom with a labeled ${ }^{15} \mathrm{~N}$ atom (Fig. 4a), whereas ${ }^{30} \mathrm{~N}_{2}$ is produced from the coupling of two labeled ${ }^{15} \mathrm{~N}$ atoms (Fig. 4b). Using combinations of different labeled $\mathrm{N}$ species, it is possible to identify the source of $\mathrm{N}$ used to produce $\mathrm{N}_{2}$. Volume specific rates were calculated by least squares regressions through the linear periods of $\mathrm{N}_{2}$ production. These rates are presented in Table 1, and a summary of the expected and observed incorporation of ${ }^{15} \mathrm{~N}$-labeled $\mathrm{N}$ into $\mathrm{N}_{2}$ is presented in Table 2. In treatments $\mathrm{A}, \mathrm{D}$, and $\mathrm{E}$, in which the only labeled nitrogen was in the form of ammonium, there was no production of labeled $\mathrm{N}_{2}$. In treatments B, $\mathrm{C}$ and $\mathrm{F}$, which all contained labeled nitrate, there was abundant production of labeled $\mathrm{N}_{2}$. Thus, in these experiments, the production of isotopically labeled $\mathrm{N}_{2}$ requires the addition of labeled nitrate. Measurements of dissimilatory nitrate reduction (DNRA) in treatment $\mathrm{B}$ yielded volume specific rates of $1.7 \pm 0.2 \times 10^{-6} \mu \mathrm{mol} \mathrm{cm}{ }^{-3} \mathrm{~h}^{-1}$. Details of each incubation series and their interpretation with respect to sediment $\mathrm{N}$ transformations are discussed below. 


\subsection{Extractions}

The $1 \mathrm{M}$ hydroxylamine $\mathrm{HCl}$ extraction of wet sediments from the upper $2 \mathrm{~cm}$ of the core liberated $1.5 \pm$ $0.1 \mu \mathrm{mol} \mathrm{Mng}{ }^{-1}$ and $37 \pm 3 \mu \mathrm{molFe} \mathrm{g}^{-1}$, and the citratedithionite extraction liberated $0.3 \pm 0.03 \mu \mathrm{mol} \mathrm{Mn} \mathrm{g}^{-1}$ of wet sediment and $37 \pm 4 \mu \mathrm{mol} \mathrm{Fe}{ }^{-1}$ of wet sediment. A porosity of 0.87 (Mucci, unpublished results) and a sediment density of $2.65 \mathrm{~g} \mathrm{~cm}^{-3}$ (Anschutz et al., 2000) yields the volume specific solid phase Mn and Fe (hydr)oxide concentrations presented in Table 3.

\subsection{Intact core incubations}

In intact core incubations, $\mathrm{O}_{2}$ and $\mathrm{NO}_{\mathrm{x}}$ enter the sediment from the overlying water. Some of this $\mathrm{O}_{2}$ is used to drive benthic nitrification, which in turn generates $\mathrm{NO}_{\mathrm{x}}$ that fuels both denitrification and anammox. As a result, anammox and denitrification proceed in the intact cores without further addition of $\mathrm{NO}_{\mathrm{x}}$, which is rapidly consumed in the closed slurries and therefore must be supplemented. The addition of $\mathrm{NO}_{3}^{-}$to the intact core incubations is solely to provide the isotopic tracer. The other advantage of using intact sediment cores over slurries is the retention of the sediment structure, which can play an important role in biogeochemical processes (Nielsen et al., 2010). Results of the intact core incubations (Table 4) provide direct measurements of $\mathrm{N}_{2}$ production rates and the identity of the responsible pathways. Both denitrification and anammox contribute to $\mathrm{N}_{2}$ production in the Lower St. Lawrence Estuary, and in situ nitrification accounts for a large fraction of the $\mathrm{NO}_{\mathrm{x}}$ supplied for both pathways. The calculations used to compute the rates we report in this paper are the same as those used by Trimmer and Nicholls (2009) and are summarized in Appendix A.

\section{Discussion}

The modern $\mathrm{N}$-cycle and its evolution through time have been recently reviewed (Canfield et al., 2010). A schematic representation of the sedimentary $\mathrm{N}$-cycle is presented in Fig. 1, which also summarizes the rates measured in this study. Of particular importance to the work presented here are the following processes: nitrification, the aerobic transformation of $\mathrm{NH}_{4}^{+}$, via $\mathrm{NH}_{2} \mathrm{OH}$ and $\mathrm{NO}_{2}^{-}$, to $\mathrm{NO}_{3}^{-}$; denitrification, the anaerobic transformation of $\mathrm{NO}_{3}^{-}$, via $\mathrm{NO}_{2}^{-}, \mathrm{NO}$, and $\mathrm{N}_{2} \mathrm{O}$, to $\mathrm{N}_{2}$; anammox, the anaerobic transformation of $\mathrm{NH}_{4}^{+}$and $\mathrm{NO}_{2}^{-}$, via $\mathrm{N}_{2} \mathrm{H}_{4}$, to $\mathrm{N}_{2}$; and dissimilatory nitrate reduction, the anaerobic reduction of $\mathrm{NO}_{3}^{-}$, via $\mathrm{NO}_{2}^{-}$, to $\mathrm{NH}_{4}^{+}$.

\subsection{Porewater profiles}

With nitrate concentrations in the LSLE bottom water on the order of $23 \mu \mathrm{moll}^{-1}$, the $\mathrm{NO}_{\mathrm{x}}$ porewater profiles (Fig. 3) show that the surface sediment is a sink for $\mathrm{NO}_{3}^{-}$from the overlying water. Undetectable $\mathrm{NH}_{4}^{+}$in the overlying water
Table 3. Extractable solid phase $\mathrm{Fe}$ and $\mathrm{Mn}$ in upper $2 \mathrm{~cm}$ of sediment.

\begin{tabular}{lrr}
\hline & $\mathrm{Mn}\left(\mu \mathrm{mol} \mathrm{cm}^{-3}\right)$ & $\mathrm{Fe}\left(\mu \mathrm{mol} \mathrm{cm}^{-3}\right)$ \\
\hline 1 M Hydroxylamine-HCl & $1.8 \pm 0.2$ & $45 \pm 3$ \\
Citrate-Dithionite & $0.3 \pm 0.04$ & $44 \pm 5$ \\
\hline
\end{tabular}

and a strong sub-surface $\mathrm{NH}_{4}^{+}$gradient imply a large upward flux of $\mathrm{NH}_{4}^{+}$towards the sediment-water interface. In the classical view of the $\mathrm{N}$-cycle, these profiles would be taken to indicate that nitrification in the oxic sediment layer is the likely sink for ammonium and that denitrification, occurring just below the oxygen penetration depth $(8-10 \mathrm{~mm}$ below the SWI), provides a sink for $\mathrm{NO}_{3}^{-}$. Nitrification and denitrification are often tightly coupled near the oxic-anoxic boundary of the sediment with little loss of fixed nitrogen $\left(\mathrm{NO}_{\mathrm{x}}\right.$ and $\mathrm{NH}_{4}^{+}$) to the overlying water (Thamdrup and Dalsgaard, 2008). With the recent discovery of anammox in natural environments, the classical view needs to be amended because anammox may serve as a sink for both $\mathrm{NH}_{4}^{+}$and $\mathrm{NO}_{3}^{-}$via the reactive intermediate $\mathrm{NO}_{2}^{-}$.

It has been proposed that $\mathrm{NH}_{4}^{+}$can be anaerobically oxidized to $\mathrm{N}_{2}, \mathrm{NO}_{2}^{-}$or $\mathrm{NO}_{3}^{-}$by $\mathrm{Mn}$ (hydr)oxides or organic complexes of $\mathrm{Fe}$ (III) and $\mathrm{Mn}$ (Mn(III/IV), which are ubiquitous and abundant in many soils and sediments (Luther et al., 1997; Hulth et al., 1999; Madison et al., 2011). These reactions are thermodynamically favorable under a variety of environmental conditions and could be globally important contributors to $\mathrm{N}$ cycling (Luther et al., 1997). The $\mathrm{Mn}$ - and $\mathrm{Fe}$ - dependent reactions are conceptually consistent with observed $\mathrm{N}$ species distributions in sediments of the Lower St. Lawrence Estuary (Luther et al., 1997; Anschutz et al., 2000), and diagenetic models incorporating these reactions accurately reproduce $\mathrm{N}$-species profiles (Katsev et al., 2007).

\subsection{Slurry incubations and $\mathrm{N}_{2}$ production pathways}

Our slurry incubations constrain the N-transformation pathways operating in St. Lawrence Estuary sediments. In treatment $\mathrm{A}$, which received an addition of ${ }^{15} \mathrm{~N}$-labeled $\mathrm{NH}_{4}^{+}$, there was no production of ${ }^{29} \mathrm{~N}_{2}$ or ${ }^{30} \mathrm{~N}_{2}$, and none of the added $\mathrm{NH}_{4}^{+}$was converted to $\mathrm{N}_{2}$ (Fig. 4). This demonstrates the absence of direct oxidation of $\mathrm{NH}_{4}^{+}$to $\mathrm{N}_{2}$ by the $\mathrm{Mn}$ (III, IV) or $\mathrm{Fe}(\mathrm{III})$ species present in these sediments. In conjunction with the results of treatment $\mathrm{B}$, it also demonstrates that $\mathrm{NH}_{4}^{+}$is not oxidized to $\mathrm{NO}_{3}^{-}$or $\mathrm{NO}_{2}^{-}$because, if it were, ${ }^{15} \mathrm{~N}$ originating from ${ }^{15} \mathrm{~N}_{-} \mathrm{NH}_{4}^{+}$would register in the $\mathrm{N}_{2}$ pool following denitrification of the newly produced ${ }^{15} \mathrm{~N}$ $\mathrm{NO}_{\mathrm{x}}$. Treatment $\mathrm{B}$, which received ${ }^{15} \mathrm{~N}-\mathrm{NO}_{3}^{-}$, produced ample ${ }^{30} \mathrm{~N}_{2}$ (Fig. 4), confirming active denitrification (discussed further below). 


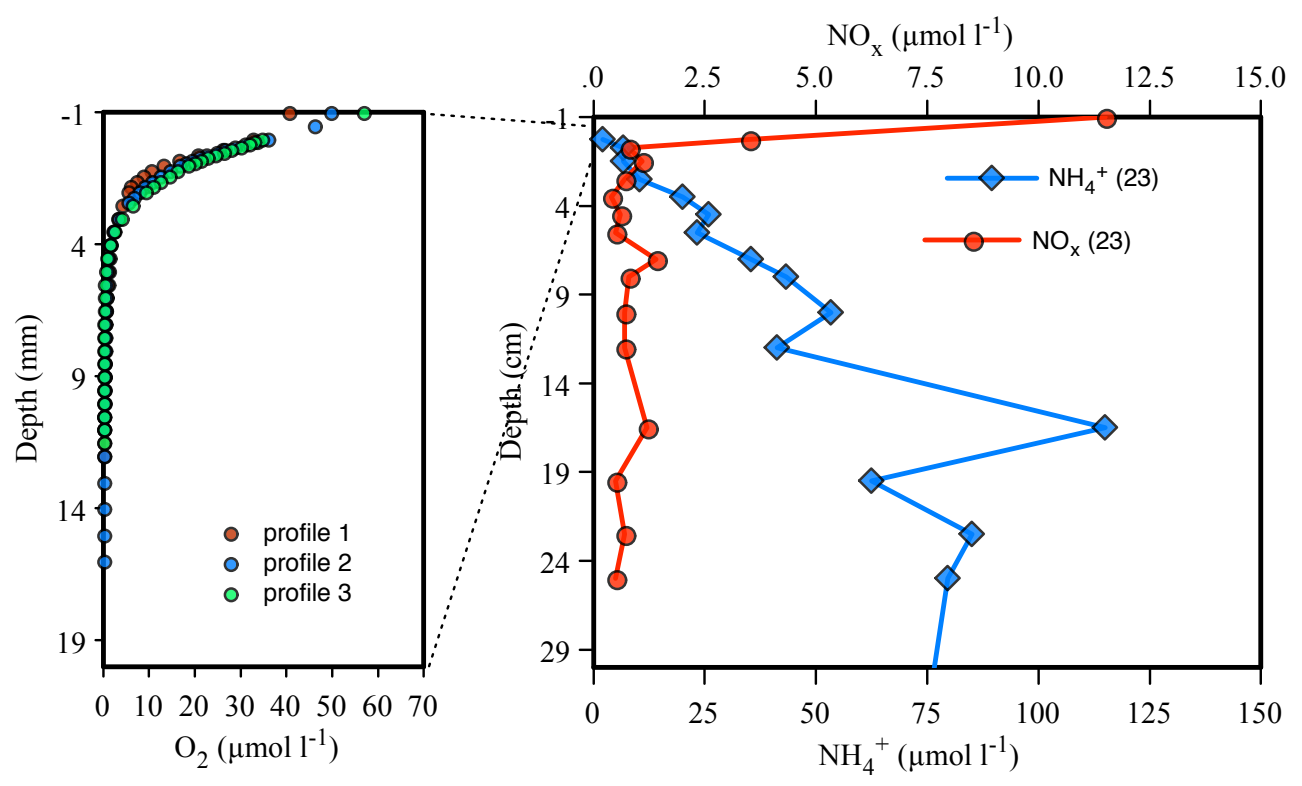

Fig. 3. Porewater profiles (a) $\mathrm{O}_{2}$, (b) $\mathrm{N}$ species.
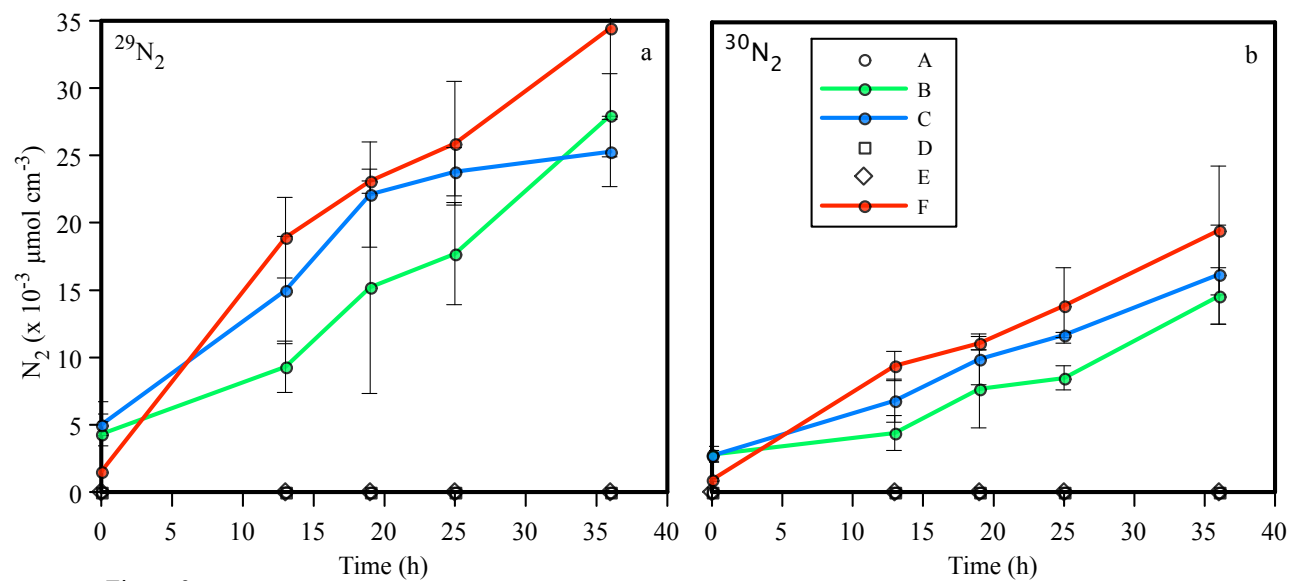

Fig. 4. Results from slurry incubations. (a) ${ }^{29} \mathrm{~N}_{2}$ production, (b) ${ }^{30} \mathrm{~N}_{2}$ production. Series A labeled with ${ }^{15} \mathrm{~N}-\mathrm{NH}_{4}$; series B labeled with ${ }^{15} \mathrm{~N}-\mathrm{NO}_{3}$; series $\mathrm{C}$ labeled with ${ }^{15} \mathrm{~N}-\mathrm{NO}_{3}$ and ${ }^{15} \mathrm{~N}-\mathrm{NH}_{4}$; series D labeled with ${ }^{15} \mathrm{~N}-\mathrm{NH}_{4}$ and spiked with allylthiourea (ATU); series E labeled with ${ }^{15} \mathrm{~N}-\mathrm{NH}_{4}$ and spiked with 40 mmol $1^{-1} \mathrm{Mn}$ (III)-pyrophosphate; series F labeled with ${ }^{15} \mathrm{~N}-\mathrm{NH}_{4}$ and ${ }^{15} \mathrm{~N}-\mathrm{NO}_{3}$ and spiked with ATU.

It could be argued that the reactive $\mathrm{Mn}$ and $\mathrm{Fe}$ pools in the sediment were rapidly consumed during the equilibration period prior to our incubations and thus were not available for the oxidation of $\mathrm{NH}_{4}^{+}$. We can constrain this argument by considering the size of the reactive $\mathrm{Mn}(\mathrm{IV})$ and $\mathrm{Fe}(\mathrm{III})$ pools, the potential rates of $\mathrm{Mn}$ and $\mathrm{Fe}$ reduction from organic matter oxidation, and the duration of the experiments. Assuming that most of the labile organic matter is mineralized within the upper $2 \mathrm{~cm}$ of the sediment, the volume specific demand for oxidants can be estimated from the published oxygen uptake rates. Taking the value of $0.43 \mu \mathrm{mol} \mathrm{cm}^{-2} \mathrm{~d}^{-1}$ for the $\mathrm{O}_{2}$ uptake (Katsev et al., 2007) and normalizing for the stoichiometry of oxic respiration, we estimate maximum volume specific $\mathrm{C}$ mineralization rates of $0.22 \mu \mathrm{mol} \mathrm{C} \mathrm{cm}{ }^{-3} \mathrm{~d}^{-1}$. These are maximum rates because of the assumption that anaerobic $\mathrm{C}$ mineralization, as would occur in our slurries, would be as rapid as aerobic $\mathrm{C}$ mineralization, although other studies indicate that $\mathrm{C}$ mineralization rates during $\mathrm{Fe}(\mathrm{III})$ and $\mathrm{Mn}(\mathrm{IV})$ reduction are slower than during oxic respiration (Magen et al., 2011). Considering the stoichiometry of $\mathrm{Mn}(\mathrm{IV})$ and $\mathrm{Fe}(\mathrm{III})$ respiration and the reactive $\mathrm{Fe}$ and $\mathrm{Mn}$ (hydr)oxide concentrations operationally defined by the $1 \mathrm{M}$ hydroxylamine- $\mathrm{HCl}$ extractions, we estimate that the reactive $\mathrm{Mn}(\mathrm{IV})$ and $\mathrm{Fe}(\mathrm{III})$ pools would be exhausted in closed anoxic incubations after 2 and 25 days, respectively. Stated differently, less than $25 \%$ of the total 
Table 4. $\mathrm{N}$ reaction rates (all in $\mu \mathrm{mol} \mathrm{N} \mathrm{m}^{-2} \mathrm{~h}^{-1}$ ).

\begin{tabular}{|c|c|c|c|c|c|}
\hline & $\begin{array}{l}\text { Thibodeau } \\
\text { et al. (2010) }\end{array}$ & $\begin{array}{r}\text { Katsev } \\
\text { et al. }(2007)\end{array}$ & $\begin{array}{r}\text { Wang } \\
\text { et al. }(2003)\end{array}$ & This study intact core & This study slurry \\
\hline $\mathrm{NO}_{3}^{-}$flux & 5.6 & 23.7 & 25.5 & $14^{\mathrm{a}}$ & \\
\hline $\mathrm{N}_{2}$ production & 24.3 & 23.3 & 3.3 & $16.8 \pm 2.0$ & 40 \\
\hline Denitrification & 26.5 & & $\mathrm{x}$ & $11.3 \pm 1.1$ & 13 \\
\hline Anammox & & & $5.5 \pm 1.7$ & 26 & \\
\hline$\%$ Anammox & & & & 32.9 & 67 \\
\hline$\%$ in situ & & & & 95 & \\
\hline Nitrification & & & & $>13$ & \\
\hline Ammonification & & & & $>16^{\mathrm{c}}$ & \\
\hline Assimilatory nitrate reduction & & & & $>13^{\mathrm{b}}$ & \\
\hline DNRA & & & & $0.005 \pm 0.0003$ & $6 \pm 1 \times 10^{-5}$ \\
\hline
\end{tabular}

reactive $\mathrm{Mn}(\mathrm{IV})$ and $<2 \%$ of reactive $\mathrm{Fe}(\mathrm{III})$ would have been consumed during our 12-h incubation period at these $\mathrm{C}$ mineralization rates. It is unlikely therefore that the supply of reactive $\mathrm{Mn}(\mathrm{IV})$ and $\mathrm{Fe}(\mathrm{III})$ would have limited $\mathrm{Mn}(\mathrm{IV})$ and $\mathrm{Fe}(\mathrm{III})$ dependent $\mathrm{NH}_{4}^{+}$oxidation during our experiments.

We also tested the hypothesis that organically-complexed $\mathrm{Mn}$ (III) species, which have recently been discovered in the Black Sea and Chesapeake Bay (Trouwborst et al., 2006) and quantitatively measured in the LSLE sediment porewaters (Madison et al., 2011), could serve as oxidants for $\mathrm{NH}_{4}^{+}$. Treatment E received both ${ }^{15} \mathrm{~N}$-labeled $\mathrm{NH}_{4}^{+}$and $\mathrm{Mn}$ (III)-pyrophosphate at a concentration of $635 \mu \mathrm{moll}^{-1}$. As with treatment $\mathrm{A}$, neither ${ }^{29} \mathrm{~N}_{2}$ nor ${ }^{30} \mathrm{~N}_{2}$ were generated during the incubation (Fig. 4), demonstrating that $\mathrm{Mn}(\mathrm{III})$ pyrophosphate is not an effective oxidant of $\mathrm{NH}_{4}^{+}$in the LSLE sediments, even at relatively high $\mathrm{Mn}$ (III) concentrations. It could be argued that $\mathrm{Mn}$ (III)-pyrophosphate is a strong complex which may not be kinetically reactive or (bio)available for $\mathrm{NH}_{4}^{+}$oxidation. Even though the $\mathrm{Mn}(\mathrm{III})$ pyrophosphate complex stability constant is poorly constrained (Klewicki and Morgan, 1998), information on its reactivity can be gleaned from published experimental data. For example, the complex reacts readily with $\mathrm{Fe}(\mathrm{II})$ and $\mathrm{HS}^{-}$ and can be used as an electron acceptor in the respiration of simple organic acids by Shewanella putrefaciens MR1 (Kostka et al., 1995). Thus, the available experimental evidence attests that both the kinetic reactivity and the bioavailability of Mn(III)-pyrophosphate make it an appropriate analogue of natural Mn(III) complexes. Our slurry experiments thus provide no evidence for the coupling of $\mathrm{Mn}(\mathrm{III} / \mathrm{IV})$ or $\mathrm{Fe}$ (III) reduction with the oxidation of $\mathrm{NH}_{4}^{+}$to $\mathrm{N}_{2}, \mathrm{NO}_{2}^{-}$or $\mathrm{NO}_{3}^{-}$. We conclude that these reactions are unlikely to take place in the LSLE sediments.

In contrast, the slurry incubations reveal that anammox occurs at high rates in LSLE sediments. In the absence of ${ }^{14} \mathrm{~N}$ $\mathrm{NO}_{3}$, which was completely consumed during the 12-h pre- equilibration period, denitrification cannot produce ${ }^{29} \mathrm{~N}_{2}$ in treatment $\mathrm{B}$, which only received ${ }^{15} \mathrm{~N}$-labeled $\mathrm{NO}_{3}^{-}$. In other words, there was no ${ }^{14} \mathrm{~N}^{-\mathrm{NO}_{3}^{-}}$available during denitrification to pair with the ${ }^{15} \mathrm{~N}-\mathrm{NO}_{3}^{-}$and form ${ }^{29} \mathrm{~N}_{2}$. Thus, we attribute the observed ${ }^{29} \mathrm{~N}_{2}$ formation (Table 1) to the anammox reaction, which in our experiment produced ${ }^{29} \mathrm{~N}_{2}$ at rates of $6.6 \pm 0.7 \times 10^{-4} \mu \mathrm{mol} \mathrm{cm}{ }^{-3} \mathrm{~h}^{-1}$, coupling ${ }^{15} \mathrm{~N}^{-\mathrm{NO}_{2}^{-}}$, produced from added ${ }^{15} \mathrm{~N}^{-\mathrm{NO}_{3}^{-}}$, with naturally-occurring ${ }^{14} \mathrm{~N}_{-} \mathrm{NH}_{4}^{+}$. As the sediment was diluted $1: 1$ with seawater, we can scale these rates up by a factor of two to estimate in situ, volume specific, anammox rates of $1.32 \pm 0.14 \times$ $10^{-3} \mu \mathrm{mol} \mathrm{cm}^{-3} \mathrm{~h}^{-1}$.

Dissimilatory $\mathrm{NO}_{3}^{-}$reduction to $\mathrm{NH}_{4}^{+}$could in principle produce ${ }^{15} \mathrm{~N}-\mathrm{NH}_{4}^{+}$from the ${ }^{15} \mathrm{~N}-\mathrm{NO}_{3}^{-}$added, which would translate to ${ }^{30} \mathrm{~N}_{2}$ production via anammox and a corresponding underestimation of total anammox rates by only considering the ${ }^{29} \mathrm{~N}_{2}$ pool. Similarly, denitrification based on ${ }^{30} \mathrm{~N}_{2}$ production would be overestimated. However, our measured rates of dissimilatory $\mathrm{NO}_{3}^{-}$reduction to $\mathrm{NH}_{4}^{+}$are two orders of magnitude lower than the denitrification and anammox rates. Thus, dissimilatory $\mathrm{NO}_{3}^{-}$reduction to $\mathrm{NH}_{4}^{+}$has an insignificant effect on our estimates of anammox and denitrification rates. From the data presented in Fig. 4b, we can estimate maximum $\mathrm{N}_{2}$ production rates from denitrification of $3.3 \pm 0.6 \times 10^{-4} \mu \mathrm{mol} \mathrm{cm}^{-3} \mathrm{~h}^{-1}$ (Table 1), and in situ rates of $6.6 \pm 1.2 \times 10^{-4} \mu \mathrm{mol} \mathrm{cm} \mathrm{cm}^{-3} \mathrm{~h}^{-1}$. In our slurry incubations, anammox would therefore account for $\geq 67 \%$ of the total $\mathrm{N}_{2}$ production.

We also tested for $\mathrm{NH}_{4}^{+}$limitation of anammox and the possibility that trace leakage of oxygen into the Exetainers might cause nitrification. To test for $\mathrm{NH}_{4}^{+}$limitation of anammox, ${ }^{15} \mathrm{~N}-\mathrm{NH}_{4}^{+}$and ${ }^{15} \mathrm{~N}-\mathrm{NO}_{3}^{-}$were added in treatment $\mathrm{C}$. Both ${ }^{29} \mathrm{~N}_{2}$ and ${ }^{30} \mathrm{~N}_{2}$ production rates were statistically equivalent to those in treatment $\mathrm{B}\left({ }^{15} \mathrm{~N}-\mathrm{NO}_{3}^{-}\right.$only, Fig. 4). This demonstrates that $\mathrm{NH}_{4}^{+}$was not limiting for anammox and 
confirms that little ${ }^{15} \mathrm{~N}-\mathrm{NH}_{4}^{+}$is incorporated into the ${ }^{30} \mathrm{~N}_{2}$ pool during anammox. This validates our measurements of dissimilatory nitrate reduction rates, which are very low, and confirms that ${ }^{30} \mathrm{~N}_{2}$ production is exclusively due to denitrification. Lack of ${ }^{29} \mathrm{~N}_{2}$ and ${ }^{30} \mathrm{~N}_{2}$ production in treatments $\mathrm{A}, \mathrm{D}$, and $\mathrm{E}$ demonstrates that nitrification rates in our slurry experiments are insignificant. Otherwise, any nitrification would be recorded in the ${ }^{29} \mathrm{~N}_{2}$ and ${ }^{30} \mathrm{~N}_{2}$ pools due to subsequent denitrification. The addition to treatment $\mathrm{F}$ of allylthiourea (ATU), a specific inhibitor of nitrification that blocks the oxidation of $\mathrm{NH}_{4}^{+}$to $\mathrm{NO}_{2}^{-}$(Hall, 1984), resulted in a weak, but statistically significant stimulation of both anammox and denitrification (Table 1). The reasons for this stimulation are unclear, but one possible explanation could be that ATU is used as an electron donor or carbon substrate by denitrifying or anammox bacteria.

The results of our slurry incubations demonstrate that $\mathrm{Mn}$ (III/IV)- and Fe(III)-dependent ammonium oxidation are not a significant component of the sedimentary $\mathrm{N}$-cycle at Station 23 in the LSLE. Anammox, on the other hand, is an important pathway for $\mathrm{N}_{2}$ production. The estimated volume specific denitrification and anammox rates are 0.66 and $1.3 \times 10^{-3} \mu \mathrm{mol} \mathrm{cm}{ }^{-3} \mathrm{~h}^{-1}$, respectively. Assuming that these rates are representative of the upper $2 \mathrm{~cm}$ of sediment and that all $\mathrm{N}_{2}$ production occurs within this interval, these rates translate to area-specific rates of 13 and $26 \mu \mathrm{mol} \mathrm{m}^{-2} \mathrm{~h}^{-1}$ for $\mathrm{N}_{2}$ production through denitrification and anammox, respectively (see Appendix for calculation details).

\subsection{Intact core incubations and in situ rates}

Although slurry incubations can constrain potential rates and the qualitative importance of different reaction pathways, many biogeochemical reactions are stimulated in such slurries. Incubations with intact sediment cores provide more realistic estimates of in situ rates. The recent development of a method to measure both denitrification and anammox in intact sediment cores allows us to partition $\mathrm{N}_{2}$ production between these reactions and provides a robust estimate of their in situ rates (Trimmer and Nicholls, 2009). Results of our intact sediment core incubations are consistent with those of our slurry experiments to the effect that both anammox and denitrification are important components of the sedimentary N-cycle in the LSLE (Tables 1 and 4). Nevertheless, the anammox reaction accounts for only $33 \%$ of total $\mathrm{N}_{2}$ production in intact cores compared to $\geq 67 \%$ in the slurries. Although both denitrification and anammox were stimulated in the slurry incubations relative to the intact core incubations, anammox was stimulated to a much larger extent. In the absence of nitrification, it is likely that the first step in denitrification, the conversion of $\mathrm{NO}_{3}^{-}$to $\mathrm{NO}_{2}^{-}$, provided ${ }^{15} \mathrm{NO}_{2}^{-}$ to fuel anammox. Given that the initial step of denitrification is energetically the most favorable (Zumft, 1997), complete denitrification may be inhibited under the electron-acceptorlimiting conditions of the slurry incubations, thus augment- ing the relative importance of anammox in the slurry relative to the whole core incubations.

Our measurements of $\mathrm{N}_{2}$ production rates in intact cores are in good agreement with previous measurements and model predictions (Table 4) (Katsev et al., 2007; Thibodeau et al., 2010), though the measurements made by MIMS are slightly, but not irreconcilably, lower (see Table 4 footnote). Despite the agreement between our measured rates and those modeled by Katsev et al. (2007), the modeled rates are based on a different set of biogeochemical reactions than those we observe. The model includes Fe(III) and Mn(IV) dependent $\mathrm{NH}_{4}^{+}$oxidation and neglects anammox. These differences would not affect the ability of the model to reproduce current rates because it was calibrated using existing measurements. Model-based predictions of future changes would, however, be unreliable if the active sedimentary processes respond differently than model reactions to environmental changes. Similarly, previous reaction rate estimates were based on different techniques with different assumptions (Wang et al., 2003; Katsev et al., 2007). For example, rates based on $\mathrm{NO}_{3}^{-}$fluxes across the sediment-water interface are blind to tightly-coupled, in situ, sedimentary nitrification and denitrification and cannot distinguish between the different possible sinks for $\mathrm{NO}_{3}^{-}$(Thibodeau et al., 2010). As anammox may contribute as much as a third of the total $\mathrm{N}_{2}$ production in sediments of the Lower St. Lawrence Estuary, it should be considered in any predictions about the future of the N-cycle in the LSLE.

In UK estuaries, the importance of anammox to $\mathrm{N}_{2}$ production correlates positively with the concentration of $\mathrm{NO}_{3}^{-}$ in the overlying water and with sediment organic carbon content, but apparently not with the reactivity of the latter (Nicholls and Trimmer, 2009). The much greater percentage of $\mathrm{N}_{2}$ production attributed to anammox in the Lower St. Lawrence Estuary cannot be ascribed to differences in organic carbon content as the sedimentary organic carbon content at our study site varies between 1.2 and $1.7 \mathrm{wt} . \%$, similar to that at Medway ( $2.0 \mathrm{wt}$. \%), which had the highest percent anammox of all the UK estuaries surveyed. Furthermore, the reactivity of organic carbon in the sediments of the LSLE, as characterized by the pseudo-first order oxic respiration reaction rate $\left(k=1.8 \mathrm{yr}^{-1}\right.$; Katsev et al., 2007), is broadly comparable to that of the UK estuaries $\left(0.6 \mathrm{yr}^{-1}\right.$; Nicholls and Trimmer, 2009). Whereas $\mathrm{NO}_{3}^{-}$concentrations in water overlying the Medway sediments $\left(7-790 \mu \mathrm{mol}^{-1}\right)$ are much higher than those in the LSLE $\left(\sim 25 \mu \mathrm{moll}^{-1}\right)$, the relationship between $\mathrm{NO}_{3}^{-}$concentrations and the importance of anammox to $\mathrm{N}_{2}$ production does not appear to apply to cross-system comparisons over large geographical distances.

By comparing the isotopic composition of the nitrate in the overlying waters and that of the $\mathrm{N}_{2}$ produced through denitrification and anammox, we can discriminate between $\mathrm{N}_{2}$ generated from $\mathrm{NO}_{3}^{-}$and $\mathrm{NO}_{2}^{-}$diffusing from the overlying water and $\mathrm{NO}_{\mathrm{x}}$ produced in the sediment via nitrification 
(see Appendix A for calculation details). These calculations suggest that most of the $\mathrm{NO}_{\mathrm{x}}$ converted to $\mathrm{N}_{2}$ through denitrification and anammox is supplied through sedimentary nitrification and that diffusion of $\mathrm{NO}_{\mathrm{x}}$ from the overlying water accounts for only $\sim 5 \%\left(1 \mu \mathrm{mol} \mathrm{m}{ }^{-2} \mathrm{~h}^{-1}\right)$ of the total $\mathrm{N}_{2}$ production. Summing the diffusive $\mathrm{NO}_{\mathrm{x}}$ fluxes of $14 \mu \mathrm{mol} \mathrm{m}{ }^{-2} \mathrm{~h}^{-1}$ (Table 4) with the rates of nitrification measured by the IPT $\left(>13 \mu \mathrm{mol} \mathrm{m} \mathrm{m}^{-2} \mathrm{~h}^{-1}\right)$ yields a total nitrate supply to the surface sediment layer of $>27 \mu \mathrm{mol} \mathrm{m}{ }^{-2} \mathrm{~h}^{-1}$. Subtracting $\mathrm{NO}_{\mathrm{x}}$ consumption through $\mathrm{N}_{2}$ production $(11.3$ and $2.75 \mu \mathrm{mol} \mathrm{m} \mathrm{m}^{-2} \mathrm{~h}^{-1}$ by denitrification and anammox, respectively) from the total $\mathrm{NO}_{\mathrm{x}}$ supply yields an unaccounted $\mathrm{NO}_{\mathrm{x}}$ sink of $>13 \mu \mathrm{mol} \mathrm{m} \mathrm{m}^{-2} \mathrm{~h}^{-1}$. As our measurements indicate that dissimilatory $\mathrm{NO}_{\mathrm{x}}$ reduction rates are low, benthic $\mathrm{NO}_{\mathrm{x}}$ assimilation may account for the discrepancy and would therefore constitute a major intermediate pathway in the removal of nitrate from the St. Lawrence Estuary. The ultimate fate of this putative, assimilated $\mathrm{N}$ is unknown at this time and is difficult to reconcile with current estimates of $\mathrm{N}$ burial (Gobeil, 2006). Alternatively, as the porewater profiles and the computed $\mathrm{NO}_{\mathrm{x}}$ fluxes were generated from a separate box core, spatial heterogeneity at Station 23 could account for some of the difference between the measured $\mathrm{NO}_{\mathrm{x}}$ sinks and the calculated sources. Our finding that DNRA rates in sediments from the LSLE are very low is consistent with the observation that DNRA is much more important in tropical estuaries than in temperate estuaries (Dong et al., 2011).

A comparison of $\mathrm{O}_{2}$ uptake rates $\left(179 \mu \mathrm{mol} \mathrm{m}{ }^{-2} \mathrm{~h}^{-1}\right.$; Katsev et al., 2007) with the oxygen demand generated from nitrification $\left(26 \mu \mathrm{mol} \mathrm{m} \mathrm{m}^{-2} \mathrm{~h}^{-1}\right)$ also indicates that nitrification is an important benthic sink for $\mathrm{O}_{2}$ in sediments from the St. Lawrence Estuary. Assuming that the sediment oxygen uptake rates are representative of the benthic $\mathrm{C}$ mineralization rates, and given the typical molar $\mathrm{C}: \mathrm{N}$ ratio of sedimentary organic matter in the LSLE (12-14; Gobeil, 2006), $\mathrm{N}$ may be liberated from organic matter at a rate of $12-$ $15 \mu \mathrm{mol} \mathrm{N} \mathrm{m}{ }^{-2} \mathrm{~h}^{-1}$, somewhat lower, but very similar to our measurements of benthic $\mathrm{N}_{2}$ production rates (Table 4 ). This agreement is consistent with the idea that benthic $\mathrm{N}_{2}$ production is limited by the supply of organic matter and the resulting availability of electron donors. The marginally higher rates of $\mathrm{N}_{2}$ production than $\mathrm{N}$ release from organic matter might be attributed to the autotrophic anammox reaction, for which the electron donor is $\mathrm{NH}_{4}^{+}$and $\mathrm{NO}_{2}^{-}$is supplied via nitrification or diffusion of $\mathrm{NO}_{\mathrm{x}}$ from the overlying water column. The agreement between the calculated rates of $\mathrm{N}$ release from organic matter $\left(12-14 \mu \mathrm{mol} \mathrm{N} \mathrm{m}{ }^{-2} \mathrm{~h}^{-1}\right)$ and our measurements of nitrification $\left(>13 \mu \mathrm{mol} \mathrm{N} \mathrm{m}{ }^{-2} \mathrm{~h}^{-1}\right)$ indicate that nitrification is very efficient. In contrast, rates of $\mathrm{N}_{2}$ production may be up to $40 \%$ lower than the total $\mathrm{NO}_{\mathrm{x}}$ supply (diffusion + nitrification), revealing an inefficient removal of fixed-N through denitrification and anammox. As mentioned above, these $\mathrm{N}$ budgets are uncertain due to spatial heterogeneity at LSLE Station 23. The extent of hetero- geneity and its implications for these $\mathrm{N}$ budgets should be addressed in future studies.

\section{Conclusions}

Anammox contributes significantly to $\mathrm{N}$ removal in sediments from the LSLE. (Hydr)oxides of Fe and Mn and organic complexes of $\mathrm{Mn}$ (III) do not appear to play an active role in sedimentary $\mathrm{NH}_{4}^{+}$oxidation and $\mathrm{N}_{2}$ production although these pathways are thermodynamically favorable. Quantitative tests of their operation in marine sediments using isotope labeling fail to detect them. Dissimilatory reduction of $\mathrm{NO}_{3}^{-}$to $\mathrm{NH}_{4}^{+}$(DRNA) in LSLE sediments occurs at rates that are 3 orders of magnitude lower than denitrification and anammox. More studies will be needed to assess if our findings apply across the entire estuary, its various sediment lithologies, and the wide range of bottom-water $\mathrm{O}_{2}$ concentrations $\left(\sim 60\right.$ to $\left.150 \mu \mathrm{mol} 1^{-1}\right)$, but this study suggests that anammox plays an important role in the nitrogen budget of the Lower St. Lawrence Estuary and in mitigating continental fluxes of fixed $\mathrm{N}$ to the ocean.

\section{Appendix A}

\section{Rate calculations}

The revised isotope pairing technique (r-IPT) (Trimmer and Nicholls, 2009) was used to estimate total $\mathrm{N}_{2}$ production, $p_{14}$ (as N) as

$r-\operatorname{IPT} p_{14}=2 r_{14}\left[p^{29} \mathrm{~N}_{2}+p^{30} \mathrm{~N}_{2}\left(1-r_{14}\right)\right]$

and anammox ( $p_{14}$ anammox $)$ as

$p_{14}$ anammox $=2 r_{14}\left(p^{29} \mathrm{~N}_{2}-2 r_{14} p^{30} \mathrm{~N}_{2}\right)$.

Denitrification is calculated by subtracting $p_{14}$ anammox Eq. (A2) from $r$-IPT $p_{14}$ Eq. (A1). $p^{29} \mathrm{~N}_{2}$ and $p^{30} \mathrm{~N}_{2}$ are the production rates of ${ }^{29} \mathrm{~N}_{2}$ and ${ }^{30} \mathrm{~N}_{2}$ after the addition of ${ }^{15} \mathrm{~N}_{-} \mathrm{NO}_{3}^{-}$. The advantage of the latest version of the $r$-IPT (Trimmer and Nicholls, 2009) lies in the estimation of the ${ }^{15} \mathrm{~N}$ distribution in $\mathrm{NO}_{3}^{-}$within the zone of sedimentary denitrification $\left(r_{14}\right)$ from measurements of the isotopic composition of $\mathrm{N}_{2} \mathrm{O}$, which is assumed to be produced only via denitrification. $r_{14}$ is estimated as

$r_{14}=p^{45} \mathrm{~N}_{2} \mathrm{O} / 2 p^{46} \mathrm{~N}_{2} \mathrm{O}$.

The contribution of $p_{14}$ supported by $\mathrm{NO}_{3}^{-}$diffusing from the overlying water column, $p_{14} \mathrm{~W}$, versus nitrate produced though sedimentary nitrifications, $p_{14} \mathrm{n}$, can be calculated as follows:

$p_{14 \mathrm{w}}=p_{14} r_{14 \mathrm{w}} / r_{14}$

$p_{14 \mathrm{n}}=p_{14}-p_{14 \mathrm{w}}$ 
where $r_{14} \mathrm{~W}$ is the ratio of ${ }^{14} \mathrm{NO}_{3}^{-}$to ${ }^{15} \mathrm{NO}_{3}^{-}$in the overlying water, calculated from measurements of $\mathrm{NO}_{3}^{-}$concentrations before the addition of the ${ }^{15} \mathrm{~N}-\mathrm{NO}_{3}^{-}$label and the concentration and volume of the ${ }^{15} \mathrm{~N}^{-\mathrm{NO}_{3}^{-}}$label. The contributions of denitrification and anammox to $p_{14} \mathrm{~W}$ and $p_{14} \mathrm{n}$ were assigned by substitution of $p_{14}$ anammox and $p_{14}$ denitrification into Eqs. (4) and (5).

Rates of dissimilatory nitrate reduction to ammonium (DNRA) were calculated as follows:

DNRA $=r_{14} p^{15} \mathrm{NH}_{4}^{+}$.

where $p^{15} \mathrm{NH}_{4}^{+}$is the production rate of labeled ${ }^{15} \mathrm{~N}-\mathrm{NH}_{4}^{+}$.

To calculate area specific rates from our slurry experiments, we first multiply the measured rates by a factor of 2 in order to correct for the $1: 1$ dilution of sediment with seawater. We then assume that the slurry rates are representative of the upper $2 \mathrm{~cm}$ of sampled sediment and multiply by $2 \mathrm{~cm}$ to convert from $\mu \mathrm{mol} \mathrm{cm} \mathrm{cm}^{-3} \mathrm{~h}^{-1}$ to $\mu \mathrm{mol} \mathrm{cm} \mathrm{cm}^{-2} \mathrm{~h}^{-1}$.

Acknowledgements. We thank Loreto De Brabandere for help in setting up the $\mathrm{N}$-isotope measurements, Bo Thamdrup for helpful suggestions and discussion, Constance Guignard for assistance in processing the sediment samples and extracting porewaters, George Luther and Brad Tebo for facilitating the collection and processing of sediment cores and for helpful suggestions. We thank Captain Baumelle and the crew of the R/V Coriolis II for providing essential assistance during field operations. We also thank CarriAyne Jones for comments and editorial suggestions. This study was funded by the Natural Sciences and Engineering Research Council of Canada (NSERC) through Ship-Time Allocation, Strategic and Discovery grants to AM and BS and a DNRF grant to DEC. SAC was supported by a NSERC PDF.

Edited by: S. Pantoja

\section{References}

Anschutz, P., Sundby, B., Lefrancois, L., Luther, G. W., and Mucci, A.: Interactions between metal oxides and species of nitrogen and iodine in bioturbated marine sediments, Geochim. Cosmochim. Ac., 64, 2751-2763, 2000.

Boudreau, B. P.: Diagenetic models and their implementation, Springer-Verlag, New York, 414 pp., 1996.

Braman, R. S. and Hendrix, S. A.: Nanogram nitrite and nitrate determination in environmental and biological-materials by vanadium(III) reduction with chemi-luminescence detection, Anal. Chem., 61, 2715-2718, 1989.

Breitburg, D. L., Hondorp, D. W., Davias, L. A., and Diaz, R. J.: Hypoxia, nitrogen, and fisheries: Integrating effects across local and global landscapes, Ann. Rev. Mar. Sci., 1, 329-349, doi:10.1146/annurev.marine.010908.163754, 2009.

Canfield, D. E., Kristensen, E., and Thamdrup, B.: Aquatic geomicrobiology, in: Advances in marine biology, edited by: Southward, A., Craig, J., Young, P. A. T., Lee, M., and Fuiman, A., Elsevier, San Diego, 640 pp., 2005.
Canfield, D. E., Glazer, A. N., and Falkowski, P. G.: The evolution and future of earth's nitrogen cycle, Science, 330, 192-196, doi:10.1126/science.1186120, 2010.

Capone, D. G., Bronk, D. A., Mulholland, M. R., and Carpenter, E. J.: Nitrogen in the marine environment, 2nd Ed., Academic Press, Burlington, 1729 pp., 2008.

Clement, J. C., Shrestha, J., Ehrenfeld, J. G., and Jaffe, P. R.: Ammonium oxidation coupled to dissimilatory reduction of iron under anaerobic conditions in wetland soils, Soil Biol. Biochem., 37, 2323-2328, doi:10.1016/j.soilbio.2005.03.027, 2005.

Cloern, J. E.: Our evolving conceptual model of the coastal eutrophication problem, Mar. Ecol.-Prog. Ser., 210, 223-253, 2001.

Codispoti, L. A., Brandes, J. A., Christensen, J. P., Devol, A. H., Naqvi, S. W. A., Paerl, H. W., and Yoshinari, T.: The oceanic fixed nitrogen and nitrous oxide budgets: Moving targets as we enter the anthropocene?, Scientia Marina, 65, 85-105, 2001.

Dalsgaard, T. and Thamdrup, B.: Factors controlling anaerobic ammonium oxidation with nitrite in marine sediments, Appl. Environ. Microbiol., 68, 3802-3808, 2002.

Dalsgaard, T., Thamdrup, B., and Canfield, D. E.: Anaerobic ammonium oxidation (anammox) in the marine environment, Res. Microbiol., 156, 457-464, doi:10.1016/j.resmic.2005.01.011, 2005.

Dong, L. F., Sobey, M. N., Smith, C. J., Rusmana, I., Phillips, W., Stott, A., Osborn, M., and Nedwell, D. B.: Dissimilatory reduction of nitrate to ammonium, not denitrification or anammox, dominates benthic nitrate reduction in tropical estuaries, Limnol. Oceanogr., 56, 279-291, 2011.

Edenborn, H. M., Mucci, A., Belzile, N., Lebel, J., Silverberg, N., and Sundby, B.: A glove box for the fine-scale subsampling of sediment box cores, Sedimentology, 33, 147-150, 1986.

Francis, C. A., Beman, J. M., and Kuypers, M. M. M.: New processes and players in the nitrogen cycle: The microbial ecology of anaerobic and archaeal ammonia oxidation, ISME Journal, 1, 19-27, doi:10.1038/ismej.2007.8, 2007.

Gilbert, D., Sundby, B., Gobeil, C., Mucci, A., and Tremblay, G. H.: A seventy-two-year record of diminishing deep-water oxygen in the st. Lawrence estuary: The northwest atlantic connection, Limnol. Oceanogr., 50, 1654-1666, 2005.

Gilbert, D., Chabot, D., Archambault, P., Rondeau, B., and Hébert, S.: Appauvrissement en oxygène dans les eaux profondes du saint-laurent marin: Causes possibles et impacts écologiques, Naturaliste Canadien, 131, 67-75, 2007.

Gobeil, C.: Biogeochemistry and chemical contamination in the St. Lawrence estuary, in: Estuaries, edited by: Wangersky, P. J., Springer-Verlag, Berlin Heidelberg, 121-147, 2006.

Grasshoff, K., Kremling, K., and Ehrhardt M.: Methods of seawater analysis, 3rd Ed., Wiley-VCH, 1999.

Hall, G. H.: Measurement of nitrification rates in lake sediments: comparison of the nitrification inhibitors nitrapyrin and allylthiourea, Microb. Ecol., 10, 25-36, 1984.

Hall, P. O. and Aller, R. C.: Rapid, small-volume, flow-injection analysis for $\sum \mathrm{CO}_{2}$ and $\mathrm{NH}_{4}^{+}$in marine and fresh-waters, Limnol. Oceanogr., 37, 1113-1119, 1992.

Hulth, S., Aller, R. C., and Gilbert, F.: Coupled anoxic nitrification manganese reduction in marine sediments, Geochim. Cosmochim. Ac., 63, 49-66, 1999.

Jensen, M. M., Kuypers, M. M. M., Lavik, G., and Thamdrup, B.: Rates and regulation of anaerobic ammonium oxidation and denitrification in the Black Sea, Limnol. Oceanogr., 53, 23-36, 2008. 
Kana, T. M., Dakrangelo, C., Oldham, J. B., Bennett, G. E., and Cornwell, J. C.: Membrane inlet mass spectrometer for rapid high-precision determination of $\mathrm{N}_{2}, \mathrm{O}_{2}$, and $\mathrm{Ar}$ in environmental water samples, Anal. Chem., 66, 4166-4170, 1994.

Katsev, S., Chaillou, G., Sundby, B., and Mucci, A.: Effects of progressive oxygen depletion on sediment diagenesis and fluxes: A model for the Lower St. Lawrence River Estuary, Limnol. Oceanogr., 52, 2555-2568, 2007.

Klewicki, J. K. and Morgan, J. J.: Kinetic behavior of Mn(III) complexes of pyrophosphate, EDTA, and citrate, Environ. Sci. Technol., 32, 2916-2922, 1998.

Konig, I., Drodt, M., Suess, E., and Trautwein, A. X.: Iron reduction through the tan-green color transition in deep-sea sediments, Geochim. Cosmochim. Ac., 61, 1679-1683, 1997.

Kostka, J. E., Luther, G. W., and Nealson, K. H.: Chemical and biological reduction of $\mathrm{Mn}$ (III)-pyrophsophate complexes - potential importance of dissolved $\mathrm{Mn}$ (III) as an environmental oxidant Geochim. Cosmochim. Ac., 59, 885-894, 1995.

Kuypers, M. M. M., Lavik, G., Woebken, D., Schmid, M., Fuchs, B. M., Amann, R., Jorgensen, B. B., and Jetten, M. S. M.: Massive nitrogen loss from the benguela upwelling system through anaerobic ammonium oxidation, P. Natl. Acad. Sci. USA, 102, 6478-6483, doi:10.1073/pnas.0502088102, 2005.

Loring, D. H. and Nota, D. J. G.: Occurrence and significance of iron, manganese, and titanium in glacial marine sediments from the Estuary of the St. Lawrence River, J. Fish. Res. Board Can., 25, 2327-2347, 1968.

Luther, G. W., Sundby, B., Lewis, B. L., Brendel, P. J., and Silverberg, N.: Interactions of manganese with the nitrogen cycle: Alternative pathways to dinitrogen, Geochim. Cosmochim. Ac., 61, 4043-4052, 1997.

Luther, G. W., Brendel, P. J., Lewis, B. L., Sundby, B., Lefrancois, L., Silverberg, N., and Nuzzio, D. B.: Simultaneous measurement of $\mathrm{O}_{2}, \mathrm{Mn}, \mathrm{Fe}, \mathrm{I}$, and $\mathrm{S}$ (II) in marine pore waters with a solid-state voltammetric microelectrode, Limnol. Oceanogr., 43, 325-333, 1998.

Lyle, M.: The brown-green color transition in marine sediments: A marker of the Fe (III)-Fe(II) redox boundary, Limnol. Oceanogr., 28, 1026-1033, 1983.

Madison, A., Tebo, B., and Luther, G. W.: Simultaneous determination of soluble manganese(III), manganese(II) and total manganese in natural (pore) waters, Talanta, 84, 374-381, 2011.

Magen, C., Mucci, A., and Sundby, B.: Reduction rates of sedimentary $\mathrm{Mn}$ and Fe oxides: An incubation experiment with Arctic Ocean sediments, Aquat. Geochem., 17, 629-643, 2011.

Meyer, R. L., Risgaard-Petersen, N., and Allen, D. E.: Correlation between anammox activity and microscale distribution of nitrite in a subtropical mangrove sediment, Appl. Environ. Microbiol., 71, 6142-6149, doi:10.1128/aem.71.10.6142-6149.2005, 2005.

Mucci, A., Sundby, B., Gehlen, M., Arakaki, T., Zhong, S., and Silverberg, N.: The fate of carbon in continental shelf sediments of eastern canada: A case study, Deep-Sea Res. Pt. II, 47, 733-760, 2000 .

Nicholls, J. C. and Trimmer, M.: Widespread occurrence of the anammox reaction in estuarine sediments, Aquat. Microb. Ecol., 55, 105-113, doi:10.3354/ame01285, 2009.

Nielsen, L. P., Risgaard-Petersen, N., Fossing, H., Christensen, P. B., and Sayama, M.: Electric currents couple spatially separated biogeochemical processes in marine sediment, Nature, 463,
1071-1074, doi:10.1038/nature08790, 2010.

Nota, D. J. G. and Loring, D. H.: Recent depositional conditions in the St. Lawrence River and Gulf - a reconnaissance survey, Mar. Geol., 2, 198-235, doi:10.1016/0025-3227(64)90040-4, 1964.

Park, W., Nam, Y. K., Lee, M. J., and Kim, T. H.: Anaerobic ammonia-oxidation coupled with $\mathrm{Fe}^{3+}$ reduction by an anaerobic culture from a piggery wastewater acclimated to $\mathrm{NH}_{4}^{+} / \mathrm{Fe}^{3+}$ medium, Biotechnol. Bioproc. E., 14, 680-685, doi:10.1007/s12257-009-0026-y, 2009.

Poulton, S. W. and Canfield, D. E.: Development of a sequential extraction procedure for iron: Implications for iron partitioning in continentally derived particulates, Chem. Geol., 214, 209-221, 2005.

Reeburgh, W. S.: An improved interstitial water sampler, Limnol. Oceanogr., 12, 163-165, 1967.

Rich, J. J., Dale, O. R., Song, B., and Ward, B. B.: Anaerobic ammonium oxidation (anammox) in chesapeake bay sediments, $\mathrm{Mi}$ crob. Ecol., 55, 311-320, doi:10.1007/s00248-007-9277-3, 2008.

Risgaard-Petersen, N., Nielsen, L. P., Rysgaard, S., Dalsgaard, T., and Meyer, R. L.: Application of the isotope pairing technique in sediments where anammox and denitrification coexist, Limnol. Oceanogr. Meth., 1, 63-73, 2003.

Risgaard-Petersen, N., Meyer, R. L., and Revsbech, N. P.: Denitrification and anaerobic ammonium oxidation in sediments: Effects of microphytobenthos and $\mathrm{NO}_{3}^{-}$, Aquat. Microb. Ecol., 40, 6776, 2005.

Rysgaard, S. and Risgaard-Petersen, N.: A sensitive method for determining nitrogen-15 isotope in urea, Mar. Biol., 128, 14931502, 1997.

Rysgaard, S., Glud, R. N., Risgaard-Petersen, N., and Dalsgaard, T.: Denitrification and anammox activity in arctic marine sediments, Limnol. Oceanogr., 49, 1493-1502, 2004.

Saucier, F. J., Roy, F., Gilbert, D., Pellerin, P., and Ritchie, H.: Modeling the formation and circulation processes of water masses and sea ice in the Gulf of St. Lawrence, Canada, J. Geophys. Res.-Oceans, 108, 3269, doi:10.1029/2000JC000686, 2003.

Schrum, H. N., Spivack, A. J., Kastner, M., and D'Hondt, S.: Sulfate-reducing ammonium oxidation: A thermodynamically feasible metabolic pathway in subseafloor sediment, Geology, 37, 939-942, doi:10.1130/g30238a.1, 2009.

Shaw, J., Gareau, P., and Courtney, R. C.: Palaeogeography of Atlantic Canada 13-0 kyr, Quaternary Sci. Rev., 21, 1861-1878, doi:10.1016/s0277-3791(02)00004-5, 2002.

Shrestha, J., Rich, J. J., Ehrenfeld, J. G., and Jaffe, P. R.: Oxidation of ammonium to nitrite under iron-reducing conditions in wetland soils laboratory, field demonstrations, and push-pull rate determination, Soil Sci., 174, 156-164, doi:10.1097/SS.0b013e3181988fbf, 2009.

Thamdrup, B. and Dalsgaard, T.: The fate of ammonium in anoxic manganese oxide-rich marine sediment, Geochim. Cosmochim. Ac., 64, 4157-4164, 2000.

Thamdrup, B. and Dalsgaard, T.: Production of $\mathrm{N}_{2}$ through anaerobic ammonium oxidation coupled to nitrate reduction in marine sediments, Appl. Environ. Microbiol., 68, 1312-1318, 2002.

Thamdrup, B. and Dalsgaard, T.: Nitrogen cycling in sediments, in: Microbial ecology of the oceans, 2nd Ed., edited by: Kirchman, D. L., John Wiley \& Sons Inc., 2008.

Thibodeau, B., de Vernal, A., and Mucci, A.: Enhanced primary productivity, organic carbon fluxes and the development of hy- 
poxic bottom waters in the Lower St. Lawrence Estuary, Eastern Canada: Micropaleontological and geochemical evidence, Mar. Geol., 231, 37-50, 2006.

Thibodeau, B., Lehmann, M. F., Kowarzyk, J., Mucci, A., Gelinas, Y., Gilbert, D., Maranger, R., and Alkhati, M.: Benthic nutrient fluxes along the Laurentian channel: Impacts on the $\mathrm{N}$ budget of the St. Lawrence marine system, Estuar. Coast. Shelf Sci., 90, 195-205, doi:10.1016/j.ecss.2010.08.015, 2010.

Trimmer, M. and Nicholls, J. C.: Production of nitrogen gas via anammox and denitrification in intact sediment cores along a continental shelf to slope transect in the North Atlantic, Limnol. Oceanogr., 54, 577-589, 2009.

Trimmer, M., Nicholls, J. C., and Deflandre, B.: Anaerobic ammonium oxidation measured in sediments along the thames estuary, United Kingdom, Appl. Environ. Microbiol., 69, 6447-6454, doi:10.1128/aem.69.11.6447-6454.2003, 2003.
Trimmer, M., Nicholls, J. C., Morley, N., Davies, C. A., and Aldridge, J.: Biphasic behavior of anammox regulated by nitrite and nitrate in an estuarine sediment, Appl. Environ. Microbiol., 71, 1923-1930, doi:10.1128/aem.71.4.1923-1930.2005, 2005.

Trimmer, M., Risgaard-Petersen, N., Nicholls, J. C., and Engstrom, P.: Direct measurement of anaerobic ammonium oxidation (anammox) and denitrification in intact sediment cores, Mar. Ecol.-Prog. Ser., 326, 37-47, 2006.

Trouwborst, R. E., Clement, B. G., Tebo, B. M., Glazer, B. T., and Luther, G. W.: Soluble Mn(III) in suboxic zones, Science, 313, 1955-1957, 2006.

Wang, F. H., Juniper, S. K., Pelegri, S. P., and Macko, S. A.: Denitrification in sediments of the Laurentian trough, St. Lawrence Estuary, Quebec, Canada, Estuar. Coast. Shelf Sci., 57, 515-522, doi:10.1016/s0272-7714(02)00396-7, 2003.

Zumft, W. G.: Cell biology and molecular basis of denitrification, Microbiol. Mol. Biol. R., 61, 533-616, 1997. 